\title{
Paleolimnological evidence reveals climate-related preeminence of cyanobacteria in a temperate meromictic lake
}

\author{
Kevin Erratt, Irena F. Creed, Elizabeth J. Favot, Irina Todoran, Vera Tai, John P. Smol, and Charles G. Trick
}

\begin{abstract}
Meromictic lakes provide a physically stable environment in which proxies for potentially harmful cyanobacteria are exceptionally well-preserved in the sediments. In Sunfish Lake, a meromictic lake that has recently become the focus of citizen concern due to the apparent rise in cyanobacteria blooms, we used a multi-proxy paleolimnological approach pairing novel spectral (i.e., VNIRS) and molecular (i.e., qPCR) assessment tools to explore long-term cyanobacteria trends. We hypothesized that climate change over the past 50 years altered the Sunfish Lake environment to favour cyanobacteria dominance, resulting in an increased incidence of bloom events. Spectral and genetic results aligned to reveal an unprecedented abundance of cyanobacteria in modern times and coincided with warmer and wetter climatic conditions in the region. Our findings offer evidence for climate-driven shifts in cyanobacteria abundance and suggest that a shift towards warmer and wetter conditions supports the rise of cyanobacteria in lakes.
\end{abstract}

Résumé : Les lacs méromictiques offrent un milieu stable sur le plan physique dans lequel des caractéristiques témoignant de la présence de cyanobactéries potentiellement nocives sont exceptionnellement bien préservées dans les sédiments. Pour le lac Sunfish, un lac méromictique qui suscite depuis peu l'inquiétude de citoyens en raison de la hausse apparente de proliférations de cyanobactéries, nous avons utilisé une approche paléolimnologique basée sur plusieurs variables substitutives qui jumèle de nouveaux outils d'évaluation spectrale (c.-à-d. VNIRS) et moléculaire (c.-à-d. qPCR) afin d'explorer les tendances à long terme des cyanobactéries. Nous avons postulé que les changements climatiques au cours des 50 dernières années ont modifié le milieu du lac Sunfish de manière à favoriser une domination des cyanobactéries qui se traduit par une incidence accrue de proliférations. Les résultats spectraux et génétiques témoignent tous deux d'une abondance sans précédent de cyanobactéries au cours des dernières décennies coïncidant avec des conditions climatiques plus chaudes et humides dans la région. Nos constatations soutiennent l'interprétation de variations induites par le climat de l'abondance de cyanobactéries et indiqueraient que le passage vers des conditions plus chaudes et humides appuie l'augmentation de cyanobactéries dans les lacs. [Traduit par la Rédaction]

\section{Introduction}

Climate change has fundamentally reshaped ecosystems on a global scale, with freshwater lakes being particularly vulnerable due to their predisposition to incorporate atmospheric and terrestrial responses (Adrian et al. 2009; Williamson et al. 2009). Many regions have undergone unprecedented warming, with northern latitudes experiencing the most rapid rates of change. Lakes situated in northern latitudes are now enduring "longer summers" (i.e., warmer and longer ice-free conditions; Sharma 2019; Smol 2019) and hydrological intensification (i.e., wetter climates) in response to rising temperatures (Trenberth 2011; Creed et al. 2015). The resultant effects of a warmer and wetter climate on limnological processes have stimulated algal production and shifted the phycological competitive coefficient towards potentially nuisance taxa, such as cyanobacteria (Carey et al. 2012; Smol 2019).
Climatic factors have been explored as potential drivers of cyanobacteria bloom formation, with the two most common variables being temperature (Paerl and Huisman 2008) and precipitation (Reichwaldt and Ghadouani 2012). Temperature effects on cyanobacteria can be direct or indirect. Direct effects are related to suggestions that cyanobacteria prefer warmer conditions, offering this taxonomic group a competitive edge under a warming climate (Huisman et al. 2018; Kosten et al. 2012). Indirect effects are related to the influence of warming on internal lake processes, such as the enhanced thermal stratification and longer ice-free seasons, which are linked to shifts in cyanobacteria phenology and bloom incidences (Wagner and Adrian 2009; Pick 2016). Precipitation effects on cyanobacteria propagation are mixed (Richardson et al. 2019). Positive growth effects are associated with external nutrient delivery, which creates a fueling effect. Adverse growth effects are linked to destratification and reduced residence time, creating turbulent conditions unsuitable

Received 22 April 2021. Accepted 10 August 2021.

K. Erratt. Department of Biology, Collaborative Science Research Building, University of Saskatchewan, 112 Science Place, Saskatoon, SK S7N 5E2, Canada. I.F. Creed. School of Environment and Sustainability, University of Saskatchewan, 117 Science Place, Saskatoon, SK S7N 5C8, Canada; Department of Biology, Western University, 1151 Richmond Street, London, ON N6A 5B7, Canada; Office of the Vice-Principal Research \& Innovation, University of Toronto Scarborough, 1265 Military Trail, Toronto, ON M1C 1A4, Canada.

E.J. Favot and J.P. Smol. Paleoecological Environmental Assessment and Research Laboratory (PEARL), Department of Biology, Queen's University, 116 Barrie Street, Kingston, ON K7L 3N6, Canada.

I. Todoran and V. Tai. Department of Biology, Western University, 1151 Richmond Street, London, ON N6A 5B7, Canada.

C.G. Trick. Department of Biology, Collaborative Science Research Building, University of Saskatchewan, 112 Science Place, Saskatoon, SK S7N 5E2, Canada; Department of Biology, Western University, 1151 Richmond Street, London, ON N6A 5B7, Canada.

Corresponding author: Irena F. Creed (email: irena.creed@utoronto.ca).

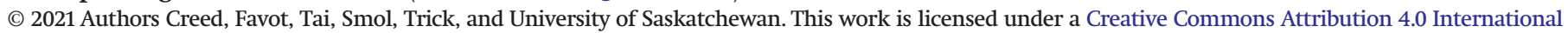
License (CC BY 4.0), which permits unrestricted use, distribution, and reproduction in any medium, provided the original author(s) and source are credited. 
Fig. 1. Sunfish Lake is located in the middle reaches of the Schneider Creek Sub-Watershed $\left(326 \mathrm{~km}^{2}\right)$ in the mid-reaches of the Grand River Watershed $\left(6778 \mathrm{~km}^{2}\right)$ in Ontario, Canada, draining into Lake Erie: (a) land cover as percentages of total area in the Grand River Watershed in 2015; (b) land cover as percentages of total area within a $1 \mathrm{~km}$ buffer of Sunfish Lake in 2015. (Data sources: North American Land Change Monitoring System (NALCMS) Land Cover 30 m, 2015 (Landsat and RapidEye) (http://www.cec.org/north-american-environmental-atlas/ land-cover-30m-2015-landsat-and-rapideye/); Ontario Ministry of Natural Resources and Forestry, Ontario Watershed Boundaries (OWB) (https://geohub.lio.gov.on.ca/datasets/mnrf::ontario-watershed-boundaries-owb)).

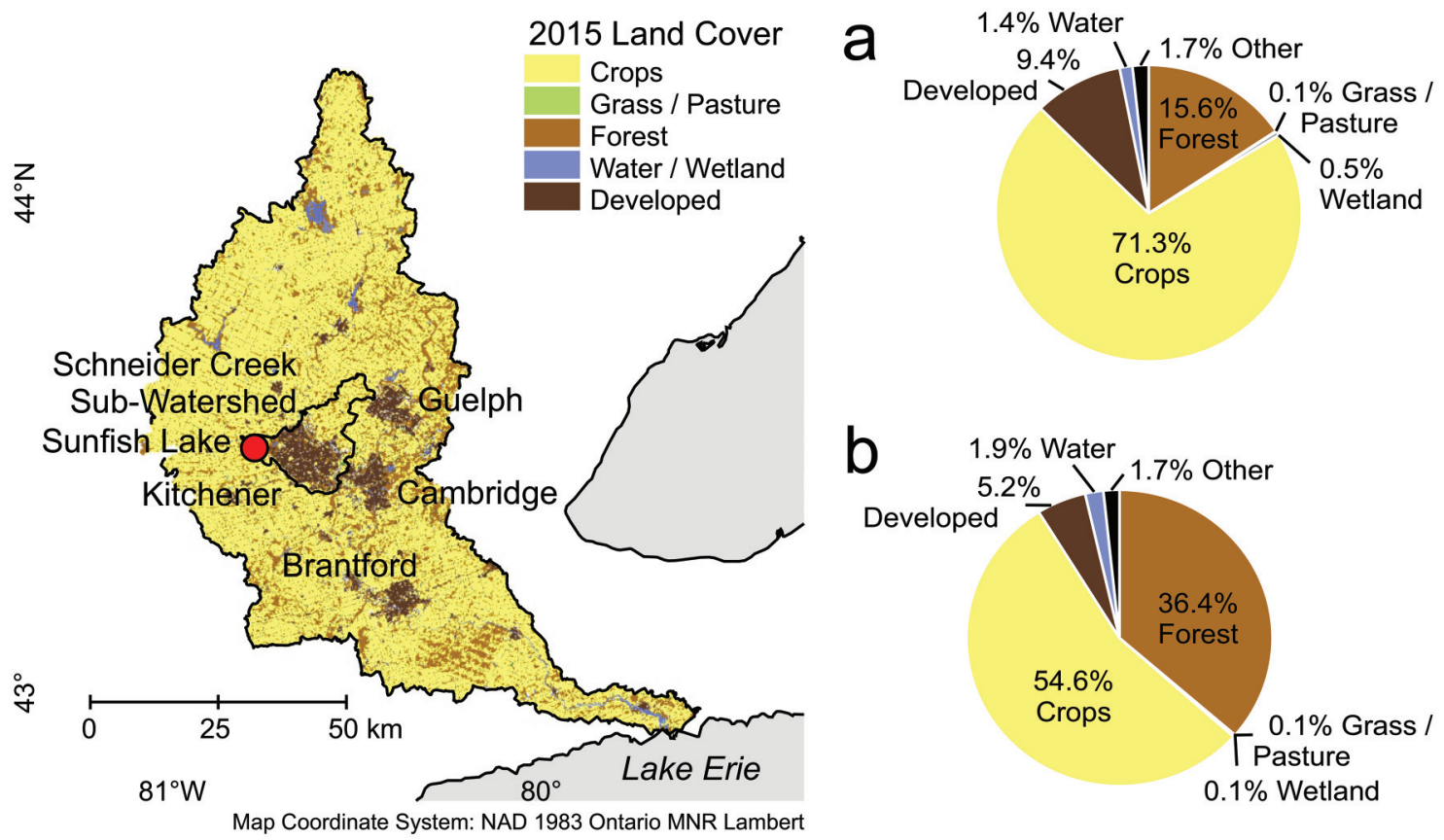

for many bloom-forming taxa (Reichwaldt and Ghadouani 2012; Richardson et al. 2019). While each climatic variable has the potential to stimulate cyanobacteria growth independently, the interactive effects of temperature and precipitation further modify lake processes to favour cyanobacteria dominance (O’Neil et al. 2012; Huisman et al. 2018).

A growing number of studies are using paleolimnological techniques to reconstruct historical cyanobacteria abundance in lakes with known, present-day cyanobacteria blooms (e.g., Pal et al. 2015; Taranu et al. 2015; Favot et al. 2019). A diversity of paleolimnological techniques have been deployed, such as pigment and molecular estimations, each possessing their own unique caveats (Pal et al. 2015). Chlorophyll $a$ is a proxy for total algal biomass, a pigment that resides in all major phycological groups (Michelutti and Smol 2016). The emerging spectral techniques to assess trends in primary production (i.e., chlorophyll a) are concordant with traditional methods, while being highly reproducible and less prone to some diagenetic effects and analytical variability (Rydberg et al. 2020). However, the use of spectral techniques to elucidate longterm trends in cyanobacteria requires further consideration since the diagnostic carotenoids are present in multiple taxonomic groups (Sanger 1988; Leavitt and Hodgson 2002) and reflect at close wavelengths on the electromagnetic spectrum (Favot et al. 2020). In addition, molecular tools are increasingly being used to examine the historical prevalence of cyanobacteria and toxinproducing genes (Rinta-Kanto et al. 2005; Domaizon et al. 2013; $\mathrm{Pal}$ et al. 2015). The success of molecular techniques relies on the preservation of DNA in sediments, which varies depending on environmental conditions. Further, the taxonomic specificity of the primers used to amplify the genetic marker region can misconstrue results if inadequately applied (Willerslev and Cooper 2005; Anderson-Carpenter et al. 2011; Pal et al. 2015). Combining trends in algal photosynthetic pigments with molecular tools is a useful approach to reconstruct the historical presence of cyanobacteria, as it cross-validates and reveals inconsistencies in emerging methodologies (Favot et al. 2020) and offers the potential of identifying phytoplankton to finer taxonomic levels (Domaizon et al. 2013; Pal et al. 2015; Pilon et al. 2019).

Here, we combine paleolimnological evidence (i.e., spectral analysis and molecular techniques) to explore whether different paleolimnological techniques converge on similar long-term trends in cyanobacteria abundance in Sunfish Lake, located in Ontario, Canada. In addition, as a meromictic lake, Sunfish Lake provides a lake of "opportunity" to explore the effects of climate change on potentially harmful cyanobacteria blooms within this region. Meromictic lakes are characterized by a catchment and lake morphology that minimizes the effect of wind mixing, creating a permanently stratified vertical water structure with warm surface waters, a strong thermocline, and deoxygenated bottom waters (Duthie and Carter 1970). Permanent stratification creates stable environments, with undisturbed sediment accumulation (i.e., low turbulence) and perpetual anoxia aiding in the preservation of molecular markers left behind by organisms, such as photosynthetic pigments and genetic material (Giguet-Covex et al. 2019). Thus, meromictic lakes create highly favourable conditions for archiving phytoplankton production, relative to holomictic systems, in which sediment disruption and oxygenation events can alter preservation rates (Blais and Kalff 1995). We test the hypothesis that climatic variability has created conditions more conducive to cyanobacteria, that is a shift towards a wetter, warmer, and longer ice-free periods (Smol 2019). Photosynthetic pigment and molecular profiles were assessed in Sunfish Lake sediments to establish trends in cyanobacteria production and explore if climatic variability is related to increases in cyanobacteria abundance using a multidisciplinary approach. 
Fig. 2. Bathymetry of Sunfish Lake, with the coring location indicated by a filled circle (adapted from Ontario Ministry of Natural Resources and Forestry, Bathymetry, Line; https:|geohub.lio.gov.on.ca/datasets/ mnrf::bathymetry-line/about).

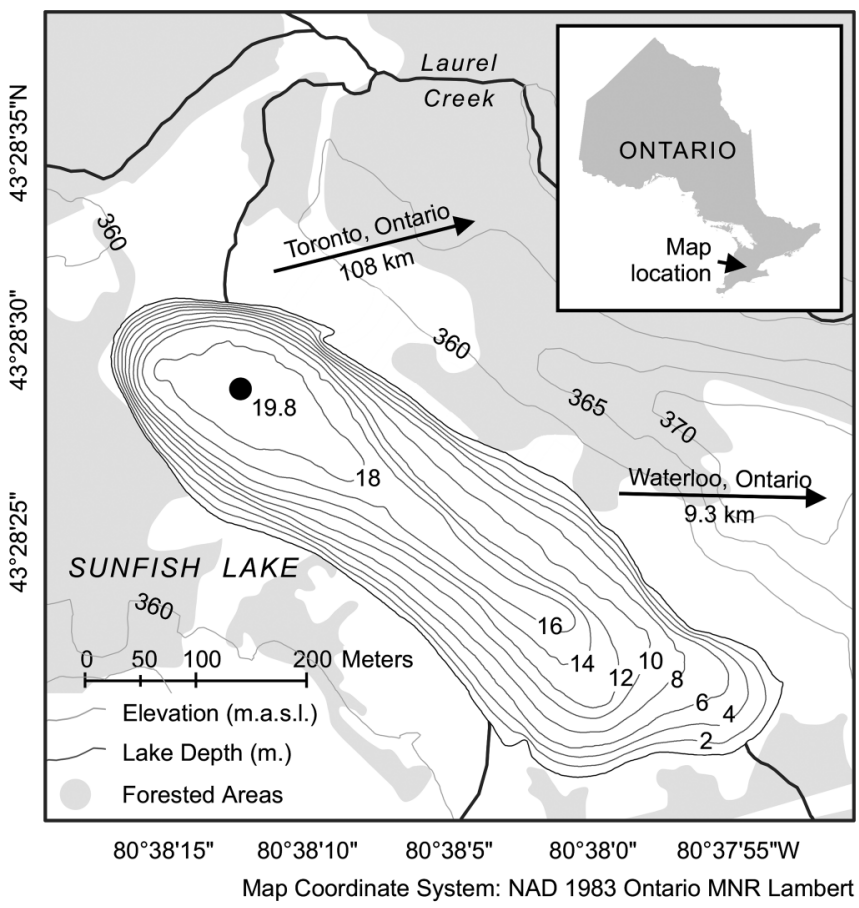

\section{Methods}

\section{Study site description}

Sunfish Lake $\left(43^{\circ} 28^{\prime} 25^{\prime \prime} \mathrm{N}, 80^{\circ} 38^{\prime} 01^{\prime \prime} \mathrm{W}, 360 \mathrm{~m}\right.$ a.s.1.) is located in the middle reaches of the Schneider Creek Sub-Watershed $\left(326 \mathrm{~km}^{2}\right)$ in the mid-reaches of the Grand River Watershed $\left(6778 \mathrm{~km}^{2}\right)$ in Ontario, Canada, draining into Lake Erie (Fig. 1). The lake is a small kettle lake situated in the township of Wilmot, adjacent to Waterloo, Ontario, Canada. The lake is long, narrow, and has two deep recesses. The northwestern recess reaches a maximum depth of $19.8 \mathrm{~m}$, whereas the southeastern recess reaches a maximum depth of $16 \mathrm{~m}$ (Fig. 2; Ontario Ministry of Natural Resources and Forestry 2020). The narrow littoral zone has remained largely absent of aquatic macrophytes; Chara patches exist in a few locations, with limited harvest efforts occurring in the early 1980s (Duthie and Carter 1970). Sunfish Lake is situated in an agricultural catchment, a feature that has kept the lake in a chronically enriched state, with total phosphorus concentrations remaining relatively constant $\left(\sim 10 \mu \mathrm{g} \cdot \mathrm{L}^{-1}\right.$ over the last 50 years; Federation of Ontario Cottager's Associations 2021).

\section{Climate correlates of phytoplankton}

Climate data (temperature and precipitation; wind data were not available) from 1911 to 2018 were obtained from the closest meteorological recording station with the most prolonged meteorological recording period, Woodstock, Ontario $\left(42^{\circ} 28^{\prime} 08^{\prime \prime} \mathrm{N}\right.$, $67^{\circ} 32^{\prime} 34^{\prime \prime} \mathrm{W}$ ), located $37.7 \mathrm{~km}$ southwest of Sunfish Lake. The water year of 1 November to 31 October was used to estimate climate correlates of phytoplankton; the water year, also known as the hydrological year, estimates annual precipitation that falls in late autumn that accumulates as snow and does not drain into the lake until the following spring's snowmelt. This study focused on assessing trends ( $Z$ scores) and opted for total water year precipitation due to the uncertainty surrounding assigning sediment sections to individual water years.

Ice-off and ice-on dates were derived using formulae from Williams and Stefan (2006) (eqs. 1 and 2):

$$
\begin{array}{r}
\text { Ice-off date }=-3.81 \times \mathrm{T}_{\text {FMAMJ }}+0.936 \times \text { Lat }+0.018 \times \text { Ele } \\
+0.157 \times H+76.7
\end{array}
$$

where $T_{\text {FMAMJ }}$ is the mean air temperature for February-June $\left({ }^{\circ} \mathrm{C}\right)$, Lat is the latitude of the lake $\left(43.474^{\circ} \mathrm{N}\right)$, Ele is the elevation $(360 \mathrm{~m})$, and $H$ is the mean depth of the lake $(10.4 \mathrm{~m})$.

$$
\begin{array}{r}
\text { Ice-on date }=1.719 \times T_{\text {SOND }}-1.672 \times \text { Lat }-0.013 \times \text { Ele } \\
+0.0016 \times A+0.146 \times H+408.8
\end{array}
$$

where $T_{\mathrm{SOND}}$ is the mean air temperature for September-December $\left({ }^{\circ} \mathrm{C}\right)$, Lat is the latitude of the lake $\left(43.474^{\circ} \mathrm{N}\right)$, Ele is the elevation $(360 \mathrm{~m}), A$ is the lake area $\left(0.077 \mathrm{~km}^{2}\right)$, and $H$ is the mean depth of the lake (10.4 m).

From the ice-on and ice-off dates, the following climate correlates were derived: duration of the ice-free period (days), mean average, mean minimum and mean maximum temperatures $\left({ }^{\circ} \mathrm{C}\right)$ for the ice-free period, mean monthly maximum temperature $\left({ }^{\circ} \mathrm{C}\right)$ during the ice-free period and total precipitation $(\mathrm{mm})$ during the ice-free period.

The following climate correlates were derived for the water year (1 November to 31 October): mean average, mean minimum and mean maximum temperatures $\left({ }^{\circ} \mathrm{C}\right)$, and total precipitation (mm).

\section{Sediment sampling and analyses}

A $60 \mathrm{~cm}$ long sediment core was collected on 17 September 2019, at the deepest point of Sunfish Lake $\left(43^{\circ} 28^{\prime} 30.3^{\prime \prime} \mathrm{N}, 80^{\circ} 38^{\prime} 10.3^{\prime \prime} \mathrm{W}\right)$ using a Glew modified gravity corer (Glew 1988) and immediately sectioned onshore. Sediment cores were extruded and sectioned in the field; by extruding high-resolution cores in the field, we eliminated the possibility of physical mixing of the sediments in transport back to the laboratory. Several precautions were taken to reduce cross-contamination in the field. Core barrels and extruding equipment were washed in a $10 \%$ ethanol solution. The spatula was sterilized in a 70\% ethanol solution between sediment increments, and the stage was wiped to limit sediment crossover. The top $2 \mathrm{~cm}$ of the core were sectioned at $0.25 \mathrm{~cm}$ intervals to obtain a higher temporal resolution, and subsequent sediments were sectioned at $0.5 \mathrm{~cm}$ intervals. Sediment samples sectioned into sterile Whirl-Pak bags (Fisher Scientific, Canada) were promptly placed on ice for transport from the field to the laboratory and then transferred to a $-20^{\circ} \mathrm{C}$ freezer for storage before analysis.

Twenty increments (of 47) were selected from the top $30 \mathrm{~cm}$ of the core for ${ }^{210} \mathrm{~Pb}$ dating. The samples were freeze-dried, placed into gamma tubes, and sealed using 2-ton epoxy (50:50 epoxy resin and polyamine hardener) above a silicone septum. Gamma activities of the ${ }^{210} \mathrm{~Pb}$ radioisotope were measured using an Ortec germanium gamma crystal detector (Putnam Technology, Inc., Georgia, USA; Schelske et al. 1994). The concentrations of unsupported ${ }^{210} \mathrm{~Pb}$ were used to estimate the age of the sediments based on the constant rate of supply model (Appleby 2001). The ${ }^{210} \mathrm{~Pb}$ activity, age, and sedimentation rates are provided in the online Supplementary Information $1^{1}$.

\section{Pigment analysis}

The sediment increments were analyzed for trends in spectrally inferred chlorophyll $a$ (Michelutti et al. 2010; Michelutti and Smol 2016) and cyanobacteria (Favot et al. 2020). A small amount of the freeze-dried sediment from each sediment increment was

${ }^{1}$ Supplementary data are available with the article at https://doi.org/10.1139/cjfas-2021-0095. 
Table 1. Climate correlates, their rate of change over the entire time series 1911-2018, and breakpoints determined by piecewise regressions.

\begin{tabular}{lccc}
\hline & $\begin{array}{l}\text { Mean } \\
(1911-2018)\end{array}$ & $\begin{array}{l}\text { Rate of change } \\
(1911-2018)\end{array}$ & $\begin{array}{l}p \text { of overall } \\
\text { regression }\end{array}$ \\
\hline Mean monthly maximum temperature during ice-free period $\left({ }^{\circ} \mathrm{C}\right)$ & 26.63 & +0.014 & $0.0077^{*}$ \\
Total annual precipitation (1 Nov. - 31 Oct.) $(\mathrm{mm})$ & 891.40 & +3.11 & $<0.0001^{*}$ \\
Ice-free period (days) & 151.30 & +0.023 & $0.0053^{*}$ \\
\hline${ }^{*} p<0.05$. & &
\end{tabular}

passed through a $125 \mu \mathrm{m}$ sieve, placed into glass scintillation vials, and analyzed for spectral absorbance in the range of 400-2500 nm using a FOSS NIR System Model 6500 Rapid Content Analyzer (FOSS, Hilleroed, Denmark). Absorbance in the range of 650 and $700 \mathrm{~nm}$ was used to quantify chlorophyll $a$ (Michelutti et al. 2010); and the range of 400-2500 $\mathrm{nm}$ with $650-700 \mathrm{~nm}$ removed, was used to quantify cyanobacteria (Favot et al. 2020). To compare changes in these two variables that are not equal either in mass or in the potential range of physiological quota, the data was transformed into standardized anomalies (Z scores) (Keil 2019). These were calculated by taking the sample deviations from the mean and dividing that value by the standard deviation of the time series.

\section{S rRNA gene abundance}

The sediment increments were analyzed for 16S rRNA gene abundance, a gene commonly used as a marker to quantify cyanobacteria, using qPCR. Two different primer sets were used in separate qPCR assays; the first set annealing to regions of the $16 \mathrm{~S}$ rRNA gene conserved in cyanobacteria (CYAN108F (5'-ACGGGT-GAG-TAA-CRC-GTR-A-3'), and CYAN377R (5'-CCC-ATK-GCG-GAARAT-TCC-CC-3'); Urbach et al. 1992; Rinta-Kanto et al. 2005). The second set of primers were specific to Planktothrix (PLANK_F16S (5'-ATC-CAA-GTC-TGC-TGT-TAA-AGA-3'), and PLANK_R16S (5'-CTCTGC-CCC-TAC-TAC-ACT-CTA-G-3'); Ostermaier and Kurmayer 2009). To prevent cross-contamination, qPCR reactions were performed under sterile conditions in a PCR-dedicated laminar flow hood and with PCR-dedicated, bleach-sterilized pipettors. Negative control reactions without DNA added were also included with every qPCR run to test for potential cross-contamination, and none was detected.

DNA extractions were performed on $250 \mathrm{mg}$ of sediment using the ZymoBIOMICS Quick-DNA Fecal/Soil Microbe Miniprep Kit (Zymo Research, Germany). The qPCR reactions were performed with the SensiFAST SYBR No-ROX reagent kit (Bioline, London, UK) that includes SYBR, a DNA-binding fluorescent dye to quantify double-stranded DNA produced during the reaction. DNA was diluted 10-fold to decrease the effect of PCR inhibitors common in sediment samples before adding it to the qPCR reaction mix. qPCR primers $\left(400 \mathrm{nmol} \cdot \mathrm{L}^{-1}\right)$ were added to each reaction, and $0.1 \mu \mathrm{g} \cdot \mu \mathrm{L}^{-1}$ of bovine serum albumin was also added to enhance amplification. Ten-fold serial dilutions of plasmid vector DNA containing the 16S rRNA gene from a cultured Planktothrix strain (UWO 312-Planktothrix isotrhrix, isolated from Sunfish Lake) were used to generate standard curves of gene abundance in each sediment increment. The qPCR reactions were run on a Bio-Rad CFX96 Touch Real-Time PCR Detection System instrument (Bio-Rad Laboratories, Inc., California, USA) with the following thermal cycling conditions: $95{ }^{\circ} \mathrm{C}$ for $3 \mathrm{~min}$, followed by 40 amplification cycles of $95{ }^{\circ} \mathrm{C}$ for $30 \mathrm{~s}, 57^{\circ} \mathrm{C}$ for cyanobacteria primers or $60{ }^{\circ} \mathrm{C}$ for Planktothrix primers for $15 \mathrm{~s}$, and $72{ }^{\circ} \mathrm{C}$ for $20 \mathrm{~s}$. The number of 16S rRNA gene copies was calculated from the linear equation derived from the standard curve (gene copies $=e(\mathrm{Ct} / \mathrm{slope}-$ $y$ intercept)), where $\mathrm{Ct}$ is the threshold cycle number. The slope and $y$ intercept are given by the linear equation derived from the standard curve. $Z$ scores were again used to assess historical trends in the qPCR-based abundances. To check for contamination, we checked the specificity of the primers against E. coli. The qPCR analyses were run in triplicate (see Supplementary Information $2^{1}$ ).

\section{Statistical analyses}

Spearman correlation analysis was used to identify correlations among phycological markers and the climate indices used as a proxy for wetter, warmer, and more extended ice-free periods. In this study, we focused on relative trends rather than absolute differences due to the inherent uncertainty regarding biomarker preservation. To compare variables (i.e., pigments and DNA) that are not equal either in mass or in the potential range of physiological quota (i.e., spectral vs. molecular), the data was transformed into standardized anomalies ( $Z$ scores). To validate coherence among VNIRS-inferred cyanobacteria and molecular techniques, a total of 46 sediment intervals were compared for Sunfish Lake using: (1) comparative visualization of trends (i.e., visual inspection); (2) Spearman's rank correlation $\left(r_{s}\right)$ on $Z$ score data; and (3) Pearson's correlation $\left(r_{\mathrm{p}}\right)$ on generalized additive models (GAMs) of both trends to reduce the influence of temporal autocorrelation. GAMs were fitted using R programming as outlined in Simpson (2018) and significance of correlation coefficients was assessed at $p<0.05$.

\section{Results}

\section{Climate patterns}

Climate data show trends towards warmer and wetter conditions with more extended ice-free periods (Table 1; Fig. 3). Specifically, the 1980s represent the onset of a period of accelerated warming, with longer ice-free periods observed around the 1980s and elevated temperatures recorded around the 1990s. Further, while there is a steady increase in precipitation from the $1900 \mathrm{~s}$, the mid-1990s represent the onset of a steep increase in total rainfall. Spearman correlation analyses of climate indices representing these trends showed relatively weak correlations between mean maximum monthly temperature during the ice-free period $\left({ }^{\circ} \mathrm{C}\right)$, the total water year precipitation $(\mathrm{mm})$, and the ice-off day of the year (which was correlated with the ice-free period (days); Table 2).

\section{Phycological patterns}

Cyanobacteria have become an increasingly dominant component of the phytoplankton assemblage, with both the VNIRS and qPCR methodologies converging on a similar outcome. The VNIRS record suggests total algal productivity (as spectrally inferred chlorophyll $a$ ) increased from the mid-1800s corresponding with the arrival of European settlers, with a second influx observed around the 1950s, aligning with the introduction of commercial agriculture and ultimately stabilizing from the 1980s onwards. Before the 1950s, and arguably in the years before the 1980s, both molecular and spectral indicators suggest relatively low cyanobacterial abundance in the lake. Since the 1980s, cyanobacteria abundance and potential bloom frequency (characterized as greater variability or "peakiness") increased (Figs. $4 a$ 
Fig. 3. Climate correlates over the time series spanning 1911-2018. Trendlines show associated breakpoints in data as detected by piecewise regressions.

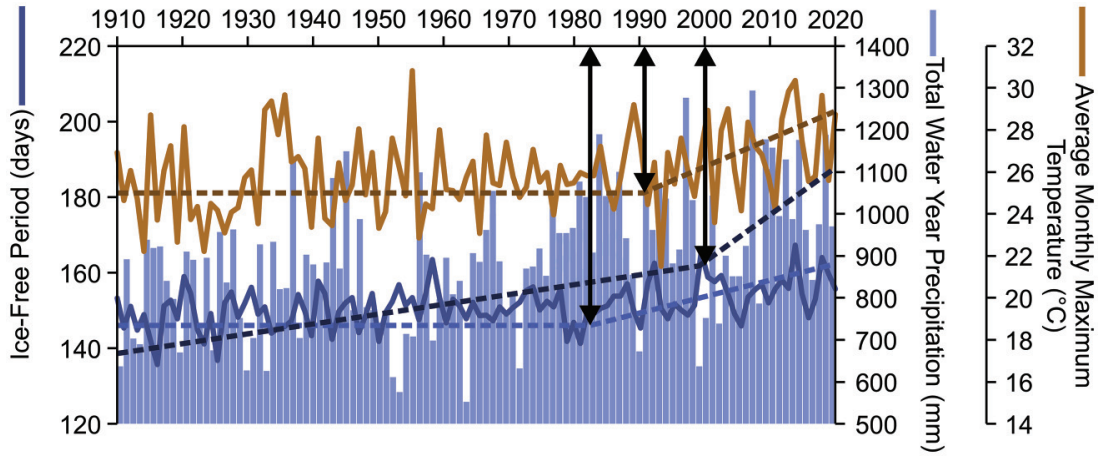

Table 2. Spearman correlation matrix of climate variables for Sunfish Lake.

\begin{tabular}{|c|c|c|c|c|c|c|}
\hline & $\begin{array}{l}\text { Mean ice-free } \\
\text { max. monthly } \\
\text { temperature }\left({ }^{\circ} \mathrm{C}\right)\end{array}$ & $\begin{array}{l}\text { Total water year } \\
\text { precipitation } \\
\left(\mathrm{mm} \cdot \text { year }^{-1}\right)\end{array}$ & $\begin{array}{l}\text { Ice-on previous } \\
\text { year (day of year) }\end{array}$ & $\begin{array}{l}\text { Ice-on } \\
\text { period } \\
\text { (days) }\end{array}$ & $\begin{array}{l}\text { Ice-off current } \\
\text { year (day of year) }\end{array}$ & $\begin{array}{l}\text { Ice-free } \\
\text { period } \\
\text { (days) }\end{array}$ \\
\hline Mean ice-free max. monthly temperature $\left({ }^{\circ} \mathrm{C}\right)$ & & -0.096 & 0.412 & -0.385 & -0.032 & $0.533^{*}$ \\
\hline Ice-on previous year (day of year) & & & & $-0.571^{*}$ & -0.303 & 0.372 \\
\hline Ice-on period (days) & & & & & 0.411 & $-0.830^{*}$ \\
\hline Ice-off current year (day of year) & & & & & & $-0.570^{*}$ \\
\hline
\end{tabular}

${ }^{*} p<0.05$.

Fig. 4. Comparison of (a) spectrally inferred chlorophyll a (filled triangles) and spectrally inferred cyanobacteria pigment (open circles) and (b) molecularly inferred cyanobacteria (open circles), and Planktothrix (filled triangles) Z scores (a constant of 10 was added for graphing purposes). Secondary $y$ axis shows associated ${ }^{210} \mathrm{~Pb}$ dates and historical events around the watershed. Spearman's rank correlation $r$ values represented as $r_{\mathrm{s}}$.

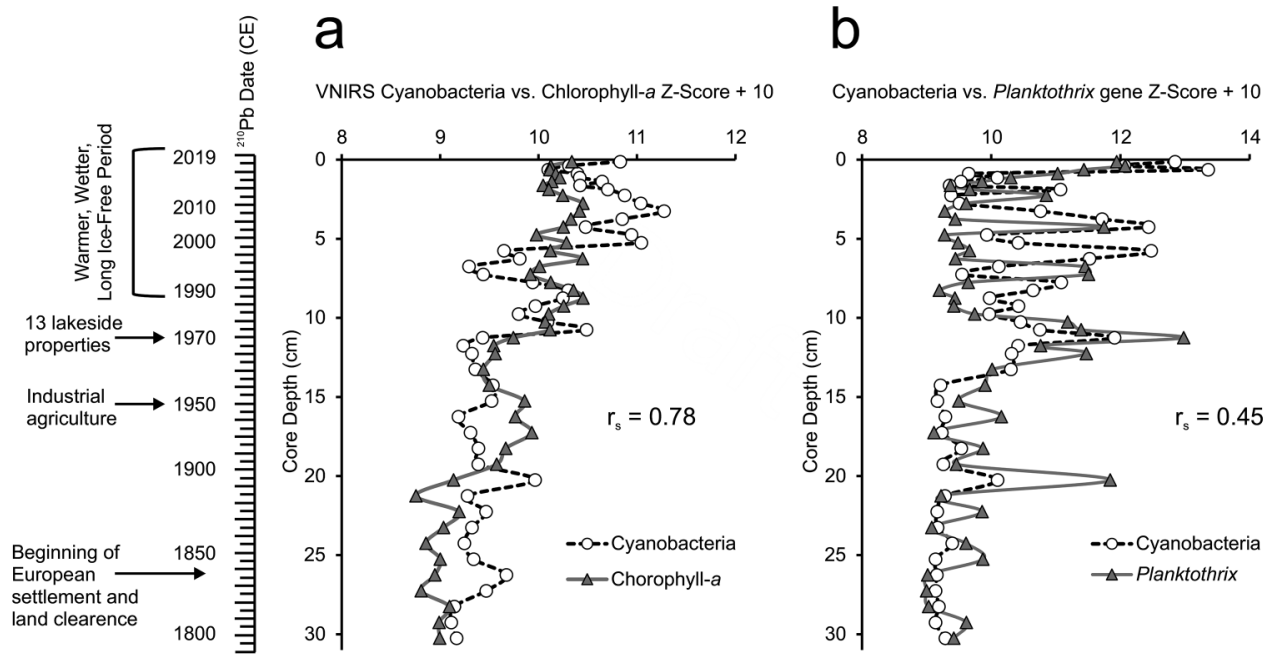

and $4 b$ ), corresponding to shifting climate variables (i.e., temperature and precipitation patterns). Although cyanobacteria populated the lake pre-1980s, cyanobacteria only became more prevalent under a warmer and wetter climate regime.

Correlation analyses revealed a significant positive relationship between cyanobacteria VNIRS and qPCR $\left(r_{\mathrm{s}}=0.49, p<0.01\right.$ and $r_{\mathrm{p}}=0.96, p<0.01$; Fig. 5). For finer taxonomic resolution, we targeted the gene of the known bloom-forming taxa in Sunfish Lake, Planktothrix. The Planktothrix and cyanobacterial gene show coherence (Fig. $4 b$ ), with a Spearman correlation showing a significant positive relationship $\left(r_{\mathrm{s}}=0.45, p<0.01\right)$, suggesting that Planktothrix may constitute a dominant component of the cyanobacterial community.

\section{Discussion}

The Earth's climate system is changing at an unprecedented rate, with marked changes observed in recent decades. The average global temperature has steadily increased, co-occurring with greater hydrological variability. Climatic scenarios project some areas, such as north temperate - subarctic regions, to face a warmer and wetter future (Trenberth 2011). Lakes are susceptible to climateinduced change due to their integrative potential (i.e., combining atmospheric, terrestrial and internal processes). High sensitivity paired with the rapid turnover of organisms (e.g., phytoplankton) creates an ideal scenario to explore even the most recent incremental alterations in climatic conditions on phycological assemblages 
Fig. 5. Comparison of downcore Z-scored VNIRS inferences of cyanobacterial abundance (black line and circles) and qPCR measures of cyanobacterial abundance (gray line and diamonds). (a) GAM trends with Pearson's correlation $r$ values represented as $r_{\mathrm{p}}$. (b) Line-and-scatter plots with Spearman's rank correlation $r$ values represented as $r_{\mathrm{s}}$.

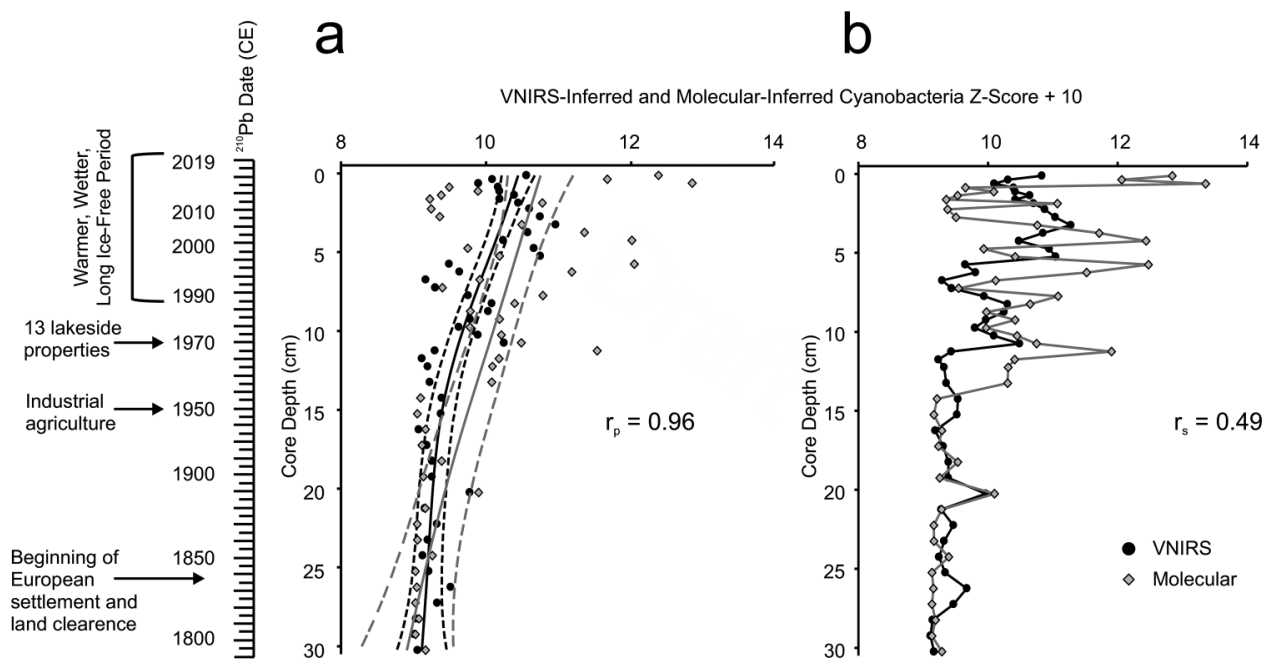

Fig. 6. Previously published and current paleorecord from Sunfish Lake. Previous research: (a) Pollen: ragweed abundance (Smol 1985); (b) Diatoms: ratio of diatom frustules to chrysophycean stomatocysts (Smol 1985); (c) Fossilized carotenoids: okenone, myxoxanthophyll and oscillaxanthin (Brown and McIntosh 1987). Sediment cores were extracted in the early 1980s, with the surface sediments reflecting this time period. Current study: (d) Spectrally inferred sedimentary chlorophyll $a$ and $(e)$ molecularly inferred sedimentary cyanobacteria abundance. Sediment core was extracted in 2019 , with $10 \mathrm{~cm}$ corresponding with the $\sim 1980 \mathrm{~s}$.
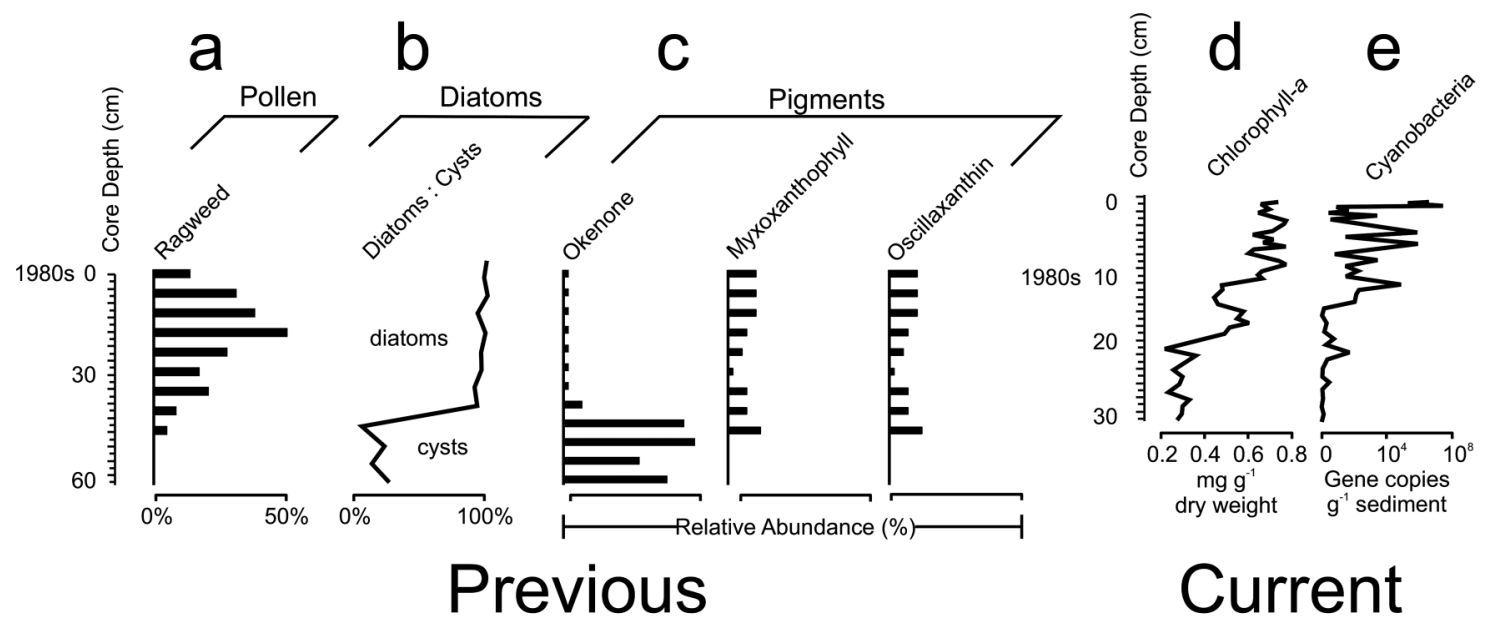

(Adrian et al. 2009; Williamson et al. 2009). Sunfish Lake’s meromictic status, paired with a history of recurrent cyanobacterial blooms, presented an important opportunity to explore novel paleolimnological techniques to investigate historical cyanobacteria dynamics and the influence of climate changes on bloom dynamics, a research area that remains understudied (Pal et al. 2015; Pilon et al. 2019; Smol 2019).

When assessing cyanobacteria abundance using qPCR and VNIRS data, both point to a trend of increasing abundance, yet high variability (i.e., distinct peaks) was observed. The sedimentary record indicates a gradual transition towards increasing cyanobacteria preeminence, which corresponds with warmer and wetter conditions in the region. The Planktothrix qPCR data revealed that Planktothrix abundance in Sunfish Lake is also highly variable. The high variability is unlike most environmental DNA (eDNA) results in paleolimnology that often show a steady incline in gene copies moving towards the surface sediments. The Planktothrix signal in Sunfish Lake had several distinct peaks, two of which coincided with two known bloom events (Duthie and Carter 1970; I. Creed, unpublished data). VNIRS is an emerging technique used to examine long-term cyanobacteria trends based on absorption spectra, and Favot et al. (2020) has demonstrated general agreement between cyanobacterial VNIRS and HPLC measures of photosynthetic pigments related to cyanobacteria (i.e., coherence between two pigment inferences). Our study builds upon Favot et al. (2020), showing coherence between molecular and novel pigment inferences, thus offering further evidence that VNIRS offers a rapid and cost-effective alternative for monitoring long-term cyanobacterial trends.

Previous paleolimnological studies have shown that Sunfish Lake has experienced phycological restructuring in response to land-use or land-cover change (Fig. 6). Historical pollen records reveal a shift from arboreal to non-arboreal taxa (i.e., grasses and ragweed) around the mid-1800s, indicative of deforestation and subsequent agricultural intensification associated with human settlements (Smol 1982, 1985). The shift from arboreal to non- 
arboreal taxa likely increased nutrient export to Sunfish Lake as indicated by signs of eutrophication in the sediment cores. For example, there was a rise in eutrophic-indicating diatoms over oligotrophic-indicating chrysophytes - a class known for being superior competitors under nutrient-poor conditions (Smol 1985) accompanied by the appearance of cyanobacteria carotenoids (myxoxanthophyll and oscillaxanthin; Brown and McIntosh 1987) in the surface sediments. Sunfish Lake is situated in an agricultural catchment, a feature that has kept Sunfish Lake in a chronically enriched state. Evidence of relatively stable TP concentrations concurring with a stabilized chlorophyll signal beginning around the 1980s suggests agricultural inputs have remained constant, and shoreline development had minimal effect on lake nutrient levels. Despite land-cover and land-use alterations playing a role in regulating phytoplankton community dynamics in Sunfish Lake earlier in the paleorecord, our findings suggest climate plays an essential role in governing cyanobacterial dynamics later in the paleorecord. However, it is important to highlight that the two drivers (i.e., nutrient subsidies and climate change) work in tandem. The external nutrient subsidies may have primed Sunfish Lake, creating nutrient conditions suitable for cyanobacterial growth. Whereas slight climatic alterations pushed the Sunfish Lake towards cyanobacteria dominance and bloom development.

Climate records show that the warmer and wetter conditions and more extended ice-free periods that began around the 1980s were associated with a systematic shift in the phytoplankton community leading to the preeminence of cyanobacteria in modern times. Temperature is a key determinant of cyanobacteria abundance (Kosten et al. 2012; Wagner and Adrian 2009). Algal biomass has been shown to increase under warming conditions, with cyanobacteria benefitting the most (Paerl and Huisman 2008; Carey et al. 2012). Cyanobacteria are presumed to have higher thermal optima relative to eukaryotic algae (Paerl and Huisman 2008; Kosten et al. 2012) and select cyanobacteria have evolved buoyancy control measures (e.g., gas vesicles), which allow cyanobacteria to withstand the constraints of stratification. Buoyancy control allows cyanobacteria to optimally position themselves for light-harvesting or obtaining nutrients accumulated at deeper depths. The combination of being "heat tolerant" and displaying buoyancy control strategies confer cyanobacteria a competitive edge in a warming world (Carey et al. 2012; Paerl and Huisman 2008). Precipitation is also a key determinant of cyanobacteria abundance (Ho and Michalak 2020). Precipitation drives the rate at which nutrients (e.g., nitrogen and phosphorus) are transported into lakes and become available for phytoplankton growth (Sinha et al. 2017), which may fuel phytoplankton blooms (Reichwaldt and Ghadouani 2012; Ho and Michalak 2020). Total water year precipitation has steadily increased in the Waterloo region since the 1900s, with a precipitous influx in modern times ( 1990s onwards; Fig. 3). Hydrological intensification strengthens terrestrial-aquatic linkages and accelerates the movement of nutrients from land to lake, which may contribute to higher algal production and cyanobacteria dominance in Sunfish Lake in modern times (Carey et al. 2012; Creed et al. 2015; Richardson et al. 2019). Finally, Sunfish Lake has historically exhibited weak meromixis, oscillating between permanent stratification periods and intermittent mixing (Duthie and Carter 1970). The gradual reduction of ice cover since the 1980s, which likely lengthened the period of thermal stratification, strengthened meromixis, which in turn creates conditions highly selective of cyanobacteria. Positively buoyant cyanobacteria genera, such as Planktothrix, benefit from increased thermal stability and their subsequent ability to outcompete their nonbuoyant counterparts for light and nutrients (Paerl et al. 2001; Carey et al. 2012).

The transition towards a warming climate, paired with increased nutrient delivery linked to wetter conditions, may explain the contemporary increase in cyanobacteria abundance in Sunfish Lake and the increased presence of Planktothrix. As warmer and wetter conditions persist and in some cases worsen, the lake structure and function will create conditions more conducive for cyanobacterial overgrowth. Our findings showcase the strength of multi-proxy studies in paleolimnology that integrate different lines of evidence that converge to establish a coherent reconstruction of past phycological change. Furthermore, the increase in cyanobacteria in Sunfish Lake was dramatic, with very little environmental signal to the citizens. Our findings illustrate that even incremental alterations in climate signals over short temporal scales can push freshwater lakes towards cyanobacteria dominance.

\section{Conclusion}

Recent changes in climate towards warmer, wetter, and more stable lake conditions are associated with shifts to greater cyanobacteria preeminence in temperate lakes. Residents surrounding Sunfish Lake raised concerns about potentially harmful cyanobacterial blooms that periodically develop. From the lake sediments, a contemporary increase in cyanobacteria was observed corresponding with recent climate change. The combination of changing climate factors (i.e., warmer, wetter and more stable conditions) may synergistically fashion an environment highly selective of potentially harmful cyanobacteria. Our data indicate, similar to other studies (some reviewed in Smol 2019), that lakes such as Sunfish Lake only required a slight climatic nudge, favouring longer growing seasons, prolonged stratification and elevated rainfall to develop problem cyanobacterial blooms. Additionally, our multidisciplinary approach, pairing molecular tools with novel pigment techniques, illustrates coherence between techniques and the potential application of these tools in future paleolimnological studies for exploring long-term cyanobacterial trends. While each methodology has imperfections, each complements one another when conjoined in a multidisciplinary design and strengthens scientific outcomes.

\section{Author contributions}

IFC conceived and designed the study. IFC and KE performed the research, including compiling, analyzing, and modelling the data. $\mathrm{KE}, \mathrm{IT}$, and VT performed and interpreted the genetic data. EJF and JPS performed and interpreted the paleolimnological data. IFC, KE, IT, and CGT wrote the paper. All contributed to editing of the paper.

\section{Acknowledgements}

We acknowledge Chris Grooms from the Paleoecological Environmental Assessment and Research Laboratory (PEARL) at Queen's University for ${ }^{210} \mathrm{~Pb}$ dating and spectral chlorophyll $a$ analyses. This work was funded by an NSERC Discovery Grants 06579-2014 and 4458-2016 awarded to IFC and CGT, respectively, and an NSERC CREATE ABATE awarded to IFC and CGT (4481722014) and Western Strategic Funds awarded to VT.

\section{References}

Adrian, R., O'Reilly, C.M., Zagarese, H., Baines, S.B., Hessen, D.O., Keller, W., et al. 2009. Lakes as sentinels of climate change. Limnol. Oceanogr. 54: 2283-2297. doi:10.4319/1o.2009.54.6_part_2.2283. PMID:20396409.

Anderson-Carpenter, L.L., McLachlan, J.S., Jackson, S.T., Kuch, M., Lumibao, C.Y., and Poinar, H.N. 2011. Ancient DNA from lake sediments: bridging the gap between paleoecology and genetics. BMC Evol. Biol. 11: 1-15.

Appleby, P.G. 2001. Chronostratigraphic techniques in recent sediments. In Tracking Environmental Change Using Lake Sediments, Basin Analysis, Coring, and Chronological Techniques. Edited by W.M. Last and J.P. Smol. Vol. 1. Springer, Dordrecht. pp. 171-203.

Blais, J.M., and Kalff, J. 1995. The influence of lake morphometry on sediment focusing. Limnol. Oceanogr. 40: 582-588. doi:10.4319/1o.1995.40.3.0582.

Brown, S.R., and McIntosh, H.J. 1987. The fossil history of sulphur phototrophs in a meromictic lake ecosystem. Acta Acad. Abo. 47: 83-95.

Carey, C.C., Ibelings, B.W., Hoffmann, E.P., Hamilton, D.P., and Brookes, J.D. 2012. Eco-physiological adaptations that favour freshwater cyanobacteria in a changing climate. Water Res. 46: 1394-1407. doi:10.1016/j.watres.2011.12.016. PMID:22217430. 
Creed, I.F., Hwang, T., Lutz, B., and Way, D. 2015. Climate warming causes intensification of the hydrological cycle, resulting in changes to the vernal and autumnal windows in a northern temperate forest. Hydrol. Process. 29: 3519-3534. doi:10.1002/hyp.10450.

Domaizon, I., Savichtcheva, O., Debroas, D., Arnaud, F., Villar, C., Pignol, C., et al. 2013. DNA from lake sediments reveals the long-term dynamics and diversity of Synechococcus assemblages. Biogeosciences, 10: 3817-3838. doi:10. 5194/bg-10-3817-2013.

Duthie, H.C., and Carter, J.C.H. 1970. The meromixis of Sunfish Lake, Southern Ontario. J. Fish. Res. Bd. Can. 27: 847-856. doi:10.1139/f70-092.

Favot, E.J., Rühland, K.M., DeSellas, A.M., Ingram, R., Paterson, A.M., and Smol, J.P. 2019. Climate variability promotes unprecedented cyanobacterial blooms in a remote, oligotrophic Ontario lake: evidence from paleolimnology. J. Paleolimnol. 62: 31-52.

Favot, E.J., Hadley, K.R., Paterson, A.M., Michelutti, N., Watson, S.B., Zastepa, A., et al. 2020. Using Visible Near-infrared Reflectance Spectroscopy (VNIRS) of lake sediments to estimate historical changes in cyanobacterial production: potential and challenges. J. Paleolimnol. 64: 335-345. doi:10.1007/s10933-02000140-2.

Federation of Ontario Cottager's Associations. 2021. Ontario lake partner program. Available from https://foca.on.ca/lake-partner-program-samplingassistance/ [accessed 7 February 2011].

Giguet-Covex, C., Ficetola, G.F., Walsh, K., Poulenard, J., Bajard, M., Fouinat, L., et al. 2019. New insights on lake sediment DNA from the catchment: importance of taphonomic and analytical issues on the record quality. Sci. Rep. 9: 14676. doi:10.1038/s41598-019-50339-1. PMID:31604959.

Glew, J.R. 1988. A portable extruding device for close interval sectioning of unconsolidated core samples. J. Paleolimnol. 1: 235-239. doi:101007/BF00177769.

Ho, J.C., and Michalak, A.M. 2020. Exploring temperature and precipitation impacts on harmful algal blooms across continental US lakes. Limnol. Oceanogr. 65: 992-1009. doi:10.1002/lno.11365.

Huisman, J., Codd, G.A., Paerl, H.W., Ibelings, B.W., Verspagen, J.M.H., and Visser, P.M. 2018. Cyanobacterial blooms. Nat. Rev. Microbiol. 16: 471-483. doi:10.1038/s41579-018-0040-1. PMID:29946124.

Keil, P. 2019. Z-scores unite pairwise indices of ecological similarity and association for binary data. Ecosphere, 10: e02933. doi:10.1002/ecs2.2933.

Kosten, S., Huszar, V.L.M., Bécares, E., Costa, L.S., Donk, E., Hansson, L.-A., et al. 2012. Warmer climates boost cyanobacterial dominance in shallow lakes. Glob. Change Biol. 18: 118-126. doi:10.1111/j.1365-2486.2011.02488.x.

Leavitt, P.R., and Hodgson, D.A. 2002. Sedimentary pigments. In Tracking Environmental Change Using Lake Sediments. Springer, Dordrecht. pp. 295-325.

Michelutti, N., and Smol, J.P. 2016. Visible spectroscopy reliably tracks trends in paleo-production. J. Paleolimnol. 56: 253-265. doi:10.1007/s10933-016-9921-3.

Michelutti, N., Blais, J.M., Cumming, B.F., Paterson, A.M., Rühland, K., Wolfe, A.P., and Smol, J.P. 2010. Do spectrally inferred determinations of chlorophyll $a$ reflect trends in lake trophic status? J. Paleolimnol. 43: 205-217. doi:10.1007| s10933-009-9325-8.

O'Neil, J.M., Davis, T.W., Burford, M.A., and Gobler, C.J. 2012. The rise of harmful cyanobacteria blooms: the potential roles of eutrophication and climate change. Harmful Algae. 14: 313-334. doi:10.1016/j.hal.2011.10.027.

Ontario Ministry of Natural Resources and Forestry. 2020. Bathymetry, Line. Dataset. Available from https://geohub.lio.gov.on.ca/datasets/mnrf::bathymetryline/about [Accessed 2 April 2020].

Ostermaier, V., and Kurmayer, R. 2009. Distribution and abundance of nontoxic mutants of cyanobacteria in lakes of the Alps. Microb. Ecol. 58: 323-333.

Paerl, H.W., and Huisman, J. 2008. Blooms like it hot. Science, 320: 57-58. doi:10.1126/science.1155398. PMID:18388279.

Paerl, H.W., Fulton, R.S., Moisander, P.H., and Dyble, J. 2001. Harmful freshwater algal blooms, with an emphasis on cyanobacteria. Sci. World J. 1: 76113. doi:10.1100/tsw.2001.16.

Pal, S., Gregory-Eaves, I., and Pick, F.R. 2015. Temporal trends in cyanobacteria revealed through DNA and pigment analyses of temperate lake sediment cores. J. Paleolimnol. 54: 87-101. doi:10.1007/s10933-015-9839-1.
Pick, F.R. 2016. Blooming algae: a Canadian perspective on the rise of toxic cyanobacteria. Can. J. Fish. Aquat. Sci. 73(7): 1149-1158. doi:10.1139/cjfas-20150470.

Pilon, S., Zastepa, A., Taranu, Z.E., Gregory-Eaves, I., Racine, M., Blais, J.M., et al. 2019. Contrasting histories of microcystin-producing cyanobacteria in two temperate lakes as inferred from quantitative sediment DNA analyses. Lake Reserv. Manag. 35: 102-117. doi:10.1080/10402381.2018.1549625.

Reichwaldt, E.S., and Ghadouani, A. 2012. Effects of rainfall patterns on toxic cyanobacterial blooms in a changing climate: between simplistic scenarios and complex dynamics. Water Res. 46: 1372-1393. doi:10.1016/j.watres.2011.11.052. PMID:22169160.

Richardson, J., Feuchtmayr, H., Miller, C., Hunter, P.D., Maberly, S.C., and Carvalho, L. 2019. Response of cyanobacteria and phytoplankton abundance to warming, extreme rainfall events and nutrient enrichment. Glob. Chang. Biol. 25: 3365-3380. doi:10.1111/gcb.14701. PMID:31095834.

Rinta-Kanto, J.M., Ouellette, A.J.A., Boyer, G.L., Twiss, M.R., Bridgeman, T.B., and Wilhelm, S.W. 2005. Quantification of toxic Microcystis spp. during the 2003 and 2004 blooms in western Lake Erie using quantitative real-time PCR. Environ. Sci. Technol. 39: 4198-4205. doi:10.1021/es048249u. PMID:15984800.

Rydberg, J., Cooke, C.A., Tolu, J., Wolfe, A.P., and Vinebrooke, R.D. 2020. An assessment of chlorophyll preservation in lake sediments using multiple analytical techniques applied to the annually laminated lake sediments of Nylandssjön. J. Paleolimnol. 64: 379-388. doi:10.1007/s10933-020-00143-z.

Sanger, J.E. 1988. Fossil pigments in paleoecology and paleolimnology. Palaeogeogr. Palaeoclimatol. Palaeoecol. 62: 343-359. doi:10.1016/0031-0182(88)90061-2.

Schelske, C.L., Peplow, A., Brenner, M., and Spencer, C.N. 1994. Low-background gamma counting: applications for ${ }^{210} \mathrm{~Pb}$ dating of sediments. J. Paleolimnol. 10: 115-128. doi:10.1007/BF00682508.

Sharma, S., Blagrave, K., Magnuson, J.J., O’Reilly, C.M., Oliver, S., Batt, R.D., et al. 2019. Widespread loss of lake ice around the Northern Hemisphere in a warming world. Nat. Clim. Chang. 9: 227-231. doi:10.1038/s41558-018-0393-5.

Simpson, G.L. 2018. Modelling palaeoecological time series using generalized additive models. Front. Ecol. Evol. 6: 149. doi:10.3389/fevo.2018.00149.

Sinha, E., Michalak, A.M., and Balaji, V. 2017. Eutrophication will increase during the 21st century as a result of precipitation changes. Science, 357: 405-408. doi:10.1126/science.aan2409. PMID:28751610.

Smol, J.P. 1982. Postglacial changes in fossil algal assemblages from three Canadian lakes. Ph.D. thesis, Queen's University, Kingston, Ont.

Smol, J.P. 1985. The ratio of diatom frustules to chrysophycean statospores: a useful paleolimnological index. Hydrobiologia, 123: 199-208. doi:10.1007/BF00034378.

Smol, J.P. 2019. Under the radar: long term perspectives on ecological changes in lakes. Proc. Royal Soc. B, 286: 201990834. doi:10.1098/rspb.2019.0834.

Taranu, Z.E., Gregory-Eaves, I., Leavitt, P.R., Bunting, L., Buchaca, T., Catalan, J., et al. 2015. Acceleration of cyanobacterial dominance in north temperatesubarctic lakes during the Anthropocene. Ecol. Lett. 18: 375-384. doi:10.1111/ ele.12420. PMID:25728551.

Trenberth, K.E. 2011. Changes in precipitation with climate change. Clim. Res. 47: 123-138. doi:10.3354/cr00953.

Urbach, E., Robertson, D.L., and Chisholm, S.W. 1992. Multiple evolutionary origins of prochlorophytes within the cyanobacterial radiation. Nature, 355: 267-270. doi:10.1038/355267a0. PMID:1731225.

Wagner, C., and Adrian, R. 2009. Cyanobacteria dominance: quantifying the effects of climate change. Limnol. Oceanogr. 54: 2460-2468. doi:10.4319/1o. 2009.54.6_part_2.2460.

Willerslev, E., and Cooper, A. 2005. Ancient DNA. Proc. Royal Soc. B. 272: 3-16.

Williams, S.G., and Stefan, H.G. 2006. Modelling of lake ice characteristics in North America using climate, geography, and lake bathymetry. J. Cold Reg. Eng., ASCE, 20: 140-167. doi:10.1061/(ASCE)0887-381X(2006)20:4(140).

Williamson, C.E., Saros, J.E., Vincent, W.F., and Smol, J.P. 2009. Lakes and reservoirs as sentinels, integrators, and regulators of climate change. Limnol. Oceanogr. 54: 2273-2282. doi:10.4319/1o.2009.54.6_part_2.2273. 